\title{
The detection of female cell activity in male sex-chromosome chimeric Rideau Arcott sheep, using the Xist gene product as a marker
}

\author{
Okimi Peters and W. Allan King
}

This manuscript was prepared for the 2007 Summer Leadership and Research Program under the supervision of Prof. W. Allan King, Department of Biomedical Sciences, Ontario Veterinary College.

\begin{abstract}
The detection of the $S R Y$ (Sex-determining region on the $\mathrm{Y}$ chromosome) gene is a popular method used for the identification of freemartins (XX/XY female chimeras). This method relies on the fact that the SRY gene is a $\mathrm{Y}$ chromosome specific gene and is thus normally only present in males. Therefore detecting its presence in a female indicates the presence of male cells (XY cells) within the female. This concept can be extrapolated to the male counterparts of freemartins with regards to the Xist gene. This gene is normally only widely expressed in females and can be used as a marker for identifying females. Therefore, detecting Xist gene expression in males (in tissues other than the testes, as the Xist gene is expressed exclusively in the testes of males) may indicate that these males contain transcriptionally competent female cells and thus necessarily labels them as sex-chromosome chimeras. In the present study four previously identified male sex chromosome chimeras were screened for the expression of the Xist gene using reverse transcription Polymerase Chain Reaction (PCR), and it was detected in three of the four chimeras. Xist expression was not detected in one of the chimeras because the proportion of female cells in its blood is significantly lower and thus it is likely that the blood sample used in the study did not possess female cells. None-the-less it was concluded that the detection of Xist expression in male sex chromosome chimeras can be used as an indication of the presence and transcriptional competence of female cells within them.
\end{abstract}

$\mathrm{I}_{\mathrm{x}}^{\mathrm{n}}$ order to compensate for the difference in the number of $\mathrm{X}$ chromosomes between the sexes, females have evolved an epigenetic compensatory mechanism which involves the inactivation of one $\mathrm{X}$ chromosome in each of their cells (with the exception of oocytes) as early as the eight-cell stage during embryogenesis. ${ }^{21}$ This inactivation process is mediated by the $\mathrm{X}$ inactivation Center (Xic), which contains the $\mathrm{X}$ inactivation specific transcript (Xist) gene as well as other genes which encode transcription factors (enhancers and repressors) involved in the process. ${ }^{30,49}$ Of particular interest in the inactivation process of placental mammals is the Xist gene which encodes Xist ribonucleic acid (RNA) as its final product, unlike other genes which encode protein as their final product. ${ }^{42}$ The $\mathrm{X}$ chromosome to be inactivated is determined by the Xic and it has been shown that there has to be physical interaction between the Xics of the two $\mathrm{X}$ chromosomes in a female cell before the expression of the Xist gene occurs. ${ }^{35}$ To initiate the inactivation process, the Xist gene is expressed from the Xic of the $\mathrm{X}$ chromosome to be inactivated. ${ }^{14}$ At this point, Tsix, which is a gene located antisense to the Xist gene and constitutively expressed on both $\mathrm{X}$ chromosomes (to antagonize the effects of the Xist gene), is down-regulated on the chromosome to be inactivated. ${ }^{33}$ The Xist RNA then forms two stable stem loop structures which fully coat the $\mathrm{X}$ chromosome to mediate heterochromatin modifications resulting in the transcriptional inactivity of the chromosome. ${ }^{37}$ These changes include histone acetylation, DNA methylation, low levels of histone $\mathrm{H} 3$ lysine-4 methylation, and high levels of histone $\mathrm{H} 3$ lysine-9 methylation. These processes result in the formation of a Barr body (which is composed of the inactivated $\mathrm{X}$ chromosome and Xist RNA) that is generally located on the periphery of the nucleus and replicates late in the cell cycle. ${ }^{14}$ The process of $\mathrm{X}$ inactivation is a very gradual process beginning with the inactivation of genes in direct proximity to the Xic (e.g. Pgk1; Phosphoglycerate kinase 1) and then spreading centrally from the Xic to other genes along the chromosome (e.g. Hprt; Hypoxanthine-guanine phosphoribosyltransferase). ${ }^{28}$ Although the Xist gene is constitutively expressed in female cells, studies have shown that the Xist RNA is primarily only involved in the initiation of the inactivation process. ${ }^{31}$ Deoxyribonucleic acid (DNA) 
methylation and Polycomb group (PcG) proteins have been implicated in the maintenance of transcriptional repression in the inactive $\mathrm{X}$ chromosome. ${ }^{5}$

The importance of the $\mathrm{X}$ inactivation process has been demonstrated through experiments which studied individuals with defects in the genes necessary for $\mathrm{X}$ inactivation. Females which fail to inactivate at least one $\mathrm{X}$ chromosome in each cell are developmentally retarded whereas those which inactivate both $\mathrm{X}$ chromosomes die before reaching the blastocyst stage during embryogenesis. ${ }^{28}$

Unlike females who are predisposed to inactivate one $\mathrm{X}$ chromosome in each of their cells, Xist-mediated $\mathrm{X}$ chromosome inactivation in males is restricted to the testes. ${ }^{45}$ During spermatogenesis the lone $\mathrm{X}$ chromosome present in developing sperm cells is transiently inactivated. The inactivation process may prevent deleterious, illegitimate recombination events between the unpaired regions of the sex chromosomes and other chromosomes during meiosis. ${ }^{25}$ Circumstantial evidence has linked failures in the meiotic $\mathrm{X}$ inactivation process in males to sub-fertility and even sterility. $^{45}$

The main focus of the present experiment was to screen for Xist gene expression in male sex chromosome chimeras (XY/XX chimeras). Although the majority of the cells present in these organisms comprise male cells, these organisms also possess female cells. Male sex chromosome chimeras can be formed by the fusion of two or more embryos of different sexes as well as cell traffic through the placenta between mother and male fetus. However, the most commonly reported mechanism of their formation involves the fusion of placental blood vessels between twins of opposite sex during pregnancy in sheep. ${ }^{12}$ It has been suggested that sheep with twin pregnancy are more genetically susceptible to the placental blood vessel fusion process. ${ }^{27}$ The fusion of placental blood vessels results in a shared common circulation which allows for cell traffic between the twins. If hematopoietic stem cells are trafficked from the female sibling into the male, a male sex chromosome chimera would arise because the male would now comprise two genetically distinct cells (male and female cells) which would have arisen from two different zygotes. ${ }^{36}$ If cells are trafficked in the opposite direction (that is from the male to the female) a freemartin or female sex chromosome chimera would develop. A lot of attention has been drawn to the freemartins because they tend to be sterile (representing economic loss to farmers) and develop reproductive abnormalities associated with the activity of male cells, anti-mullerian hormone and other hormones in them. They tend to develop a masculinized phenotype characterized by an enlarged clitoris, blind-ended vagina, absent cervix, male-type gonads and hypoplastic mullerian duct structures. ${ }^{12}$ Their male counterparts (male sex chromosome chimeras) on the other hand, have received little scrutiny because they tend to develop a normal reproductive system.
With the knowledge that Xist gene expression occurs in every female somatic cell whereas it is only limited to the testes in males, detecting Xist expression in somatic cells from males necessarily labels those cells as female cells and the entire organism a male sex chromosome chimera. To be consistent with this idea, the present experiment makes use of peripheral white blood cells to screen for Xist gene expression in four previously identified male sex chromosome Rideau Arcott sheep chimeras.

\section{Materials ANd MethodS}

\section{Blood Collection}

Blood samples were collected through jugular venipuncture from four previously identified chimeric rams (K300, K305, M148 and L50), a non-chimeric ram which was born of a same-sex litter (male control S235) and a ewe which was also born of a same-sex litter (female control S7). The collection was made using vacutainer $20 \mathrm{G} 1$ needles and 7 $\mathrm{ml}$ EDTA tubes. These blood samples were collected from animals at Ponsonby farm.

\section{Extraction of white blood cell layer from whole blood}

The white blood cell layer from each blood sample was extracted. The extraction of the white blood cell layer from whole blood was done using the standard phenol-chloroform protocol described by Barker ${ }^{6}$ and Brace. ${ }^{10}$

\section{Extraction of total RNA and reverse transcription}

The white blood cells in each sample were lysed with lysis buffer (0.1M Tris, 40mM EDTA, $0.5 \mathrm{mM} \mathrm{NaCl}, 0.2 \%$ SDS) and total RNA was extracted using TRIZOL ${ }^{\circledR}$ Reagent according to the manufacturer's instructions (Invitrogen Canada Inc., Burlington ON). Total RNA was treated with DNA-free ${ }^{\circledR}$ (Ambion Inc./ Austin, TX USA) and reverse transcription was carried out using Superscript II ${ }^{\circledR}$ RNase HReverse Transcriptase (Invitrogen Canada Inc., Burlington ON).

\section{Amplification of cDNA using Polymerase Chain Reaction} Using Xist primers (see Table 1) and PCR, the Xist complementary DNA (cDNA) present in each sample was amplified with AmpliTaq Gold enzyme according to the GeneAmp 10X PCR buffer II kit instructions (Applied Biosystems). In addition to the Xist cDNA amplifications, $\beta$ actin cDNA amplifications were run as a control. The samples were placed in a PTC-200 Peltier Thermal Cycler® (MJ Research, Waltham MA, USA) and the $\beta$-actin program was run for both Xist and $\beta$-actin amplifications. However $X i s t$ primers were used for Xist cDNA amplification and $\beta$ actin primers were used for $\beta$-actin cDNA amplification.

\section{Visualization of PCR products}

The PCR products along with a 100 base pair (bp) ladder (Invitrogen, $1 \mu \mathrm{g} / \mu \mathrm{l}$ ) were separated through electrophoresis 
Table 1: List of primers and their respective product sizes and DNA sequences, for the genes of interest in the present study.

\begin{tabular}{|l|l|l|l|}
\hline Primers & Product size & Position & Sequence \\
\hline$\beta$-actin & $450 \mathrm{bp}$ & Left & $\begin{array}{l}\text { 5'-ACTGGGACGAC } \\
\text { ATGGAGAAGAT-3' }\end{array}$ \\
\hline & & Right & $\begin{array}{l}\text { 5'- TGCTCGAAGTC } \\
\text { CAAGGCGACGT-3' }\end{array}$ \\
\hline Xist & $466 \mathrm{bp}$ & Left & $\begin{array}{l}\text { 5'-AGCATTGCTTA } \\
\text { GCATGGCTC-3 }\end{array}$ \\
\hline & & Right & $\begin{array}{l}\text { 5' - TGGCTGTGACC } \\
\text { GATTCTACC-3' }\end{array}$ \\
\hline
\end{tabular}

on a $1 \%$ agarose gel and stained with ethidium bromide, then visualized under a UV light with a Fluorochem ${ }^{\mathrm{TM}} 8800$ imager (AlphaInnotech) and its accompanying software.

\section{RESULTS}

Visualization of the gel containing $\beta$-actin-amplified PCR products revealed the presence of $\beta$-actin cDNA in all of the samples except water, which was run as a negative control (see Figure 1). This gel was run as positive control to ensure that the cells in each sample were transcriptionally active (and thus still alive) before they were subject to the experimental conditions. If the cells were deceased before they were exposed to experimental conditions, all the RNA in them would have been degraded, and thus $\beta$-actin would not be detected.

Visualization of the gel containing Xist-amplified PCR products, revealed the presence of Xist cDNA in the female control (S7) as well as K305, M148 and L50, contrary to the other samples (including K300, water, and the male control (S235)) in which Xist cDNA was not detected (see Figure 2).

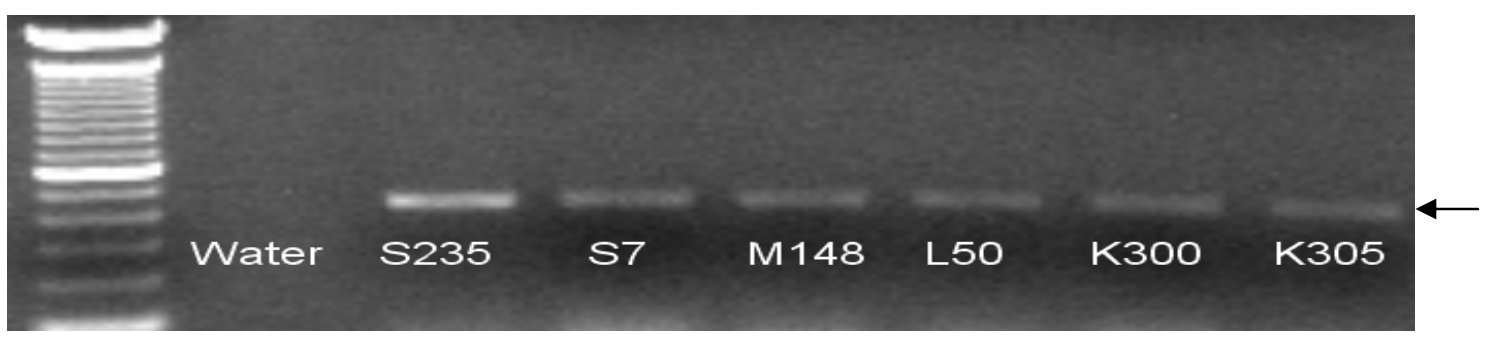

Figure 1: 1\% Ethidium Bromide agarose gel showing the presence of $\beta$-actin cDNA in each of the samples except water, which served as the negative control. The $\beta$-actin gene is a house-keeping gene, which is constitutively expressed in all cells. Therefore this gel was run as a control to ensure that the differences in Xist cDNA detection shown in Figure 2 are not due to experimental errors. Lane 1, 2, 3, 4, 5, 6, 7 and 8 contain the 100bp DNA ladder, water, S235, S7, M148, L50, K300 and K305 respectively. Note the size of the $\beta$-actin band at $450 \mathrm{bp}$.

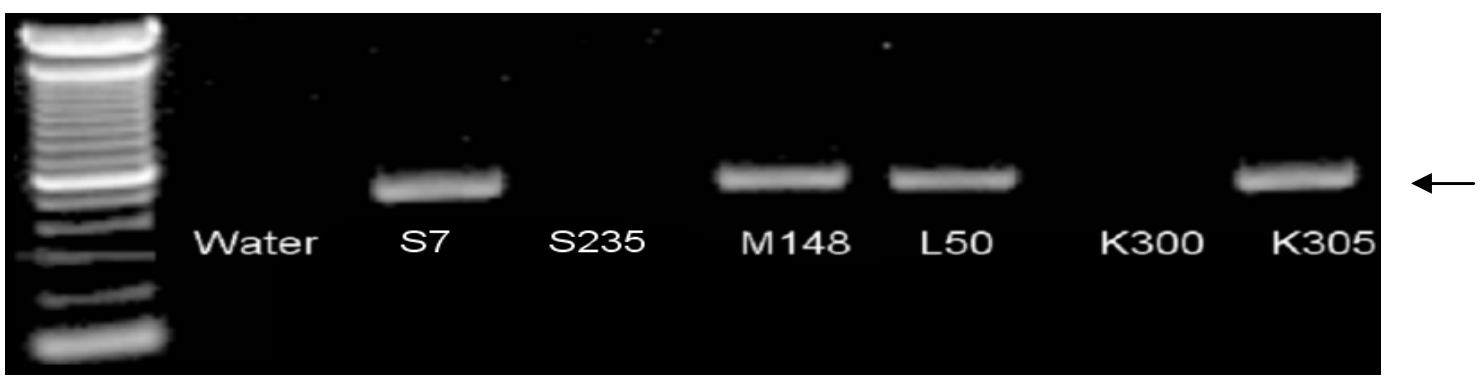

Figure 2: 1\% Ethidium Bromide agarose gel showing the samples in which Xist cDNA was detected. Lane 1 contains the 100bp DNA ladder (the bottom-most band is $100 \mathrm{bp}$ and each successive band is 100bp heavier than the one below it). Lane 2 (water) and 4 (S235) serve as negative controls while Lane 3 contains S7, the female control that serves as a positive control. Lane 5, 6, 7 and 8 contain M148 and L50, K300 and K305 respectively. Note that the Xist cDNA band is 466bp. 


\section{DiscuSSION}

Sex-chromosome chimeras (XX/XY chimeras) are usually formed by cell traffic between heterosexual twin siblings, which occurs as a result of placental blood vessel anastomosis during twin pregnancies. ${ }^{36}$ This process is thought to be controlled by a genetic process that induces aggressive and invasive blood vessel development thus increasing the probability of blood vessel fusion. ${ }^{10}$ Twin pregnancies are quite uncommon in cattle, occurring at a frequency of $0.5-2 \%$. never-the-less, sex-chromosome chimerism occurs in $92 \%$ of these cases. ${ }^{27}$ In Rideau Arcott sheep on the other hand, although twin pregnancies occur relatively frequently, sex-chromosome chimerism occurs in only $4.35 \%$ of these cases. ${ }^{10}$ Contrary to what was previously believed, Brace ${ }^{10}$ demonstrated for the first time that the incidence of sex-chromosome chimerism in these animals is independent of litter size and sex ratio, however, given that the placental structures of cattle and sheep are similar, the difference in the incidence of chimerism between both species has been attributed to a genetic process.

As opposed to their male counterparts (male sex chromosome chimeras) which develop normally, freemartins have been extensively studied due to the reproductive abnormalities often associated with them. These females usually develop masculinized reproductive phenotypes, attributable to the effects of male-specific hormones (e.g. anti-mullerian hormone) in them. In 2006, it was shown for the first time that the severity of masculinization of the reproductive tracts of freemartins is dependent on the timing of placental blood vessel anastomosis; fusions that occur much later in gestation result in less severe masculinization of the reproductive tract, presumably because by this time, female reproductive tract development would almost have been completed before being exposed to the male-specific hormones. ${ }^{10}$ It has been demonstrated that the female leukocytes in the blood of male sex chromosome chimeras (MSCC) may account for as much as $48 \%$ of the total number of leukocytes in their blood. ${ }^{10}$ Never-the-less, these males develop normal masculine reproductive tracts. ${ }^{44}$ This is consistent with the results of much earlier studies which have demonstrated that the presence of a $\mathrm{Y}$ chromosome in an individual leads to male sexual development, regardless of the number of $X$ chromosomes present. ${ }^{22}$ In normal males, the expression of the SRY gene is required for proper testis development which is in turn necessary for the circulation of anti-mullerian hormone (AMH). AMH is required for the defeminization component of male development; therefore female sexual development in MSCCs is inhibited due to the dominant effect of anti-mullerian hormone on the regression of the embryonic Mullerian duct that would otherwise give rise to the cervix, upper vagina, uterus and Fallopian tubes in normal females. ${ }^{17,50}$ At this point, the male-specific reproductive tract in MSCCs develops as a result of the effects of testosterone and dihydrotestosterone on Wollfian duct stimulation, external virilization of male genitalia and spermatogenesis. $^{20}$

The presence of female cells in male sex-chromosome chimeras has previously been described, ${ }^{10}$ but for the first time, the present study shows that these female cells are transcriptionally active. The present experiment screened for Xist gene expression (that is, Xist RNA) in four previously identified MSCCs (see Brace ${ }^{10}$ for the techniques used to identify these chimeras): M148, L50, K305 and K300. In leukocytes, Xist expression has previously been demonstrated to occur exclusively in female cells. ${ }^{45}$ However, this molecular approach was applied to MSCCs for the first time in the present study. Considering that MSCC contain female cells, the present study hypothesized that Xist gene expression would be detected in them. Indeed, this hypothesis was verified as Xist cDNA was detected in three of the four chimeras.

The percent proportion of female cells in the male sex chromosome chimeras M148, L50, K305 and K300, was previously described; ${ }^{10} \mathrm{~K} 305$ was demonstrated to comprise female leukocytes as $48 \%$ of the total number of leukocytes in its blood, while K300, M148 and L50 comprised female leukocytes as less than $1 \%$ of the total number of leukocytes in their blood. It has been demonstrated that foreign cells (female leukocytes in this case) can survive at a constant proportion throughout the lifetime of a chimera. However an inflammatory process mediated by eosinophils is responsible for the constant turnover and degradation of a majority of these foreign cells. Never-the-less, it is not fully understood why there exists such a discrepancy in the proportion of female leukocytes between chimeras such as K305 and $\mathrm{K} 300$. It has been suggested that some cells may possess a 'selective fitness' over others in a given environment thus, these cell types may be better able to survive and proliferate in some chimeras (e.g. K305) than in others (e.g. K300). This prospect may help to explain the observed difference in Xist expression between $\mathrm{K} 305$ and $\mathrm{K} 300$; Xist cDNA was detected in K305 and not K300. It is presumed that the blood sample collected from K300 lacked female leukocytes, given the very small proportion of female leukocytes that it possesses in its blood. Thus, the Xist gene would neither have been expressed in these samples nor detected.

The detection of Xist expression in males does not only indicate the presence of female cells within them, it also indicates that the female cells are transcriptionally competent. The presence of these female cells could have serious consequences on the physiology of these males as there is evidence that chimeric cells are implicated in certain autoimmune diseases, such as Hashimotos's disease, thyroiditis and systemic lupus erythematosus. Therefore, it is 
necessary to study these male chimeras further to understand the effects of female cell activity within them.

\section{Conclusion}

Based on the use of Xist-specific PCR screening, the present study shows for the first time that Xist gene expression occurs in male sex chromosome chimeras and the detection of Xist expression in these males not only suggests the presence of female cells within them, it also indicates that the female cells are transcriptionally competent.

\section{Acknowledgements}

We would like to acknowledge the contributions of Elizabeth St.John and Elizabeth Joudrey for their technical expertise. In addition, we would like to acknowledge Ponsonby Farm and NSERC for access to the experimental subjects and funding respectively.

\section{REFERENCES}

1. Adams K. Microchimerism: an investigative frontier in autoimmunity and transplantation. JAMA. 2004; 291(9): 1127- 1131.

2. Aoki R, Honma Y, Yada Y, Momoi MY, Iwamoto S. Blood chimerism in monochorionic twins conceived by induced ovulation: case report. Hum Reprod. 2006; 21(3): 735-737.

3. Ayoub N, Richler C, Wahrman J. Xist RNA is associated with the transcriptionally inactive $\mathrm{XY}$ body in mammalian male meiosis. Chromosoma (1997) 106:110.

4. Bacher CP, Guggiari M, Brors B, Augui S, Clerc P, Avner P, Eils R, Heard E. Transient colocalization of Xinactivation centres accompanies the initiation of $\mathrm{X}$ inactivation. Nat Cell Biol 2006, 8: 293-299.

5. Bantignies F, Cavalli G. Cellular memory and dynamic regulation of polycomb group proteins. Curr Opin Cell Biol2006, 18: 275-283.

6. Barker K: At the bench: a laboratory navigator. (Cold Spring Harbor Laboratory Press, New York 1998).

7. Bazopoulou-Kyrkanidou E. Chimeric creatures in Greek mythology and reflections in science. AM J Med Genet. 2001; 100(1): 66-80.

8. Boklage CE. Embryogenesis of chimeras, twins and anterior midline asymmetries, Hum reprod. 2006; 21(3): 579-591.

9. Bourdet.; Ciaudo,C.; Zakin,L.; Elalouf,J.M.; Rusniok,C.; Weissenbach,J.; Avner,P. A SAGE approach to identifying novel trans-acting factors involved in the $\mathrm{X}$ inactivation process. Cytogenet.Genome Res., 2006, 113, 1-4, 325-335, S. Karger AG, Basel, Switzerland.

10. Brace MD. Sex chromosome in Rideau Arcott sheep. Faculty of Graduate studies. University of Guelph, July, 2006.
11. Butler,M.G.; Theodoro,M.F.; Bittel,D.C.; Kuipers,P.J.; Driscoll,D.J.; Talebizadeh,Z. X-chromosome inactivation patterns in females with Prader-Willi syndrome. Am.J.Med.Genet.A., 2006.

12. Capel B, Albrecht KH, Wasburn LL, Eicher EM. Migration of mesonephric cells into the mammalian gonad depends on SRY. Mech Dev. 1999; 84(1-2): $127-$ 131.

13. Chadwick,L.H. Pertz,L.M. Broman,K.W. Bartolomei,M.S. Willard,H.F. Genetic control of X chromosome inactivation in mice: definition of the Xce candidate interval. Genetics, 2006, 173, 4, 2103-2110, United States.

14. Chow JC, Yen Z, Ziesche SM, Brown CJ. Silencing of the mammalian $\mathrm{X}$ chromosome. Annu Rev Genomics Hum Genet 2005, 6: 69-92.

15. Ciaudo,C.; Bourdet,A.; Cohen-Tannoudji,M.; Dietz,H.C.; Rougeulle,C.; Avner,P. Nuclear mRNA degradation pathway(s) are implicated in Xist regulation and X chromosome inactivation. PLoS Genet., 2006, 2, 6, e94, United States.

16. Clerc P, Avner P. Role of the region $3^{\prime}$ to Xist exon 6 in the counting process of X-chromosome inactivation. Nat Genet 1998, 19: 249-253.

17. Dabrowski T, Sysa P, Jaszczak K, Keszka J. Freemartinism in sheep. A histological analysis of the reproductive system. Animal Science Papers and Reports. 2000; 18(1): $43-63$.

18. Glander HJ. Infertility in the Klinefelter syndrome. MMW Fortschr Med. 2005 Nov 10;147(45):39-41

19. Graves JA. Sex chromosome specialization and degeneration in mammals. Cell 2006, 124: 901-914.

20. Griffin JE, Ojeda SR. Sexual differentiation. Endocrine Physiology pg 167 - 180. Oxford University Press, 2004.

21. Gupta V, Parisi M, Sturgill D, Nuttall R, Doctolero M, Dudko OK, Malley JD, Eastman PS, Oliver B . Global analysis of X-chromosome dosage compensation. $J$ Biol2006, 5: 3 .

22. Harley VR, Clarkson MJ, Argentaro A. The molecular action and regulation of the testis-determining factors, SRY (sex determining region on the $\mathrm{Y}$ chromosome0 and SOX9 [SRY-related high-mobility group (HMG) box 9]. Endocr Rev. 2003; 24(4): 466- 487.

23. Heard E and Disteche CM. Dosage compensation in mammals: fine-tuning expression of the $\mathrm{X}$ chromosome. Genes \& Dev. 2006 20: 1848-1867.

24. Herzog E, Chai L, Krause DS. Plasticity of marrowderived stem cells. Blood.2003; 102(10): 3483-93.

25. Jablonka, E. and Lamb, M.J. 1988. Meiotic pairing constraints and the activity of sex chromosomes. $J$. Theor. Biol. 133: 23-36.

26. Kay G. Xist and X chromosome inactivation. Molecular and Cellular Endocrinology 140 (1998) 71-76. 
27. Keszka J, Jaszcak K. the frequency of chromosomal $\mathrm{XX} / \mathrm{XY}$ chimerism occurrence in Merino Booroola sheep. J Appl Genet. 1996; 37(4); 367-372.

28. Latham KE, Patel B, Bautista FDM, Hawes SM. Effects of X Chromosome Number and Parental Origin on XLinked Gene Expression in Preimplantation Mouse Embryos. biology of reproduction 63, 64-73 (2000)

29. Latham KE. X chromosome imprinting and inactivation in the early mammalian embryo. TIG April 1996 Vol 12. No 4.

30. Lee JT. Regulation of X-chromosome counting by Tsix and Xite sequences. Science2005, 309: 768-771.

31. Lee JT, Lu N. Targeted mutagenesis of Tsix leads to nonrandom X inactivation. Cell 1999, 99: 47-57.

32. Lee JT, Strauss WM, Dausman JA, Jaenisch R. A 450 $\mathrm{kb}$ transgene displays properties of the mammalian $\mathrm{X}$ inactivation center. Cell 1996, 86: 83-94.

33. Lee JT, Davidow LS, Warshawsky D. Tsix, a gene antisense to Xist at the X-inactivation centre. Nat Genet 1999, 21: 400-404.

34. Lucchesi JC, Kelly WG, Panning B. Chromatin remodeling in dosagecompensation. Annu Rev Genet 2005, 39: 615-651.

35. Marahrens Y, Loring J, Jaenisch R. Role of the Xist Gene in X Chromosome Choosing. Cell, Vol. 92, 657664, March 6, 1998, Copyright 1998 by Cell Press.

36. Marcum JB. The freemartin syndrome. Anim Breed Abstr. 1974; 42(6): 227-242.

37. Ng K, Pullirsch D, Leeb M, Wutz A. Xist and the order of silencing. Embo reports, March 2007. VOL 8.

38. Nguyen DK, Disteche CM. Dosage compensation of the active X chromosome in mammals. Nat Genet 2006, 38 : 47-53.

39. Ohhata, T.; Hoki,Y.; Sasaki,H.; Sado,T. Tsix-deficient X chromosome does not undergo inactivation in the embryonic lineage in males: implications for Tsixindependent silencing of Xist. Cytogenet.Genome Res., 2006, 113, 1-4, 345-349.

40. Okamoto, I.; Heard,E.The dynamics of imprinted $\mathrm{X}$ inactivation during preimplantation development in mice. Cytogenet.Genome Res., 2006, 113, 1-4, 318-324, S. Karger AG, Basel, Switzerland.

41. Panning B, Dausman J, Jaenisch R. X chromosome inactivation is mediated by Xist RNA stabilization. Cell, Vol. 90, 907-916, September 5, 1997.

42. Plath K, Mlynarczyk-Evans S, Nusinow DA, Panning B. xist rna and the mechanism of $\mathrm{x}$ chromosome inactivation. Annu. Rev. Genet. 2002. 36:233-78.

43. Rastan S. X chromosome inactivation and the Xist gene. Genetics and Development 1994, 4:292-297.

44. Rejduch B. Kozubska-Sobocinska A, Radko, Rychlik T, Slota E. The application of genetic markers for cell chimerism diagnosis in lambs. J Anim Brre Genet. 2004; 121(3): 197-203.

45. Richler C, Seroq H, Wahrman J. X inactivation in mammalian testis is correlated with inactive $\mathrm{X}$-specific transcript. Nature Genetics, November 1992, vol 2.

46. Rychlik T, Kozubska-sobocinska A, Rejduch B, Sikora $\mathrm{T}$. The phenomenon of cell chimerism in goats. Vet. Med. - Czech, 50, 2005 (7): 311-314.

47. Sado,T.; Hoki,Y.; Sasaki,H. Tsix defective in splicing is competent to establish Xist silencing. Development, 2006, 133, 24, 4925-4931, England.

48. Selmi,C.; Invernizzi,P.; Gershwin,M.E. The X chromosome and systemic sclerosis. Curr.Opin.Rheumatol., 2006, 18, 6, 601-605, United States.

49. Vigneau,S.; Augui,S.; Navarro,P.; Avner,P.; Clerc,P. An essential role for the DXPas34 tandem repeat and Tsix transcription in the counting process of $\mathrm{X}$ chromosome inactivation. Proc.Natl.Acad.Sci.U.S.A., 2006, 103, 19, 7390-7395, United States.

50. Vilain E, McCabe ER. Mammalian sex determination: from gonads to brain. Mol Genet Metab. 1998; 65(2): 74-84.

51. Wattendorf DJ and Muenke M. Klinefelter Syndrome. Am Fam Physician 2005;72:2259-62.

52. Wutz A, Jaenisch R. A shift from reversible to irreversible $\mathrm{X}$ inactivation is triggered during ES cell differentiation. Mol Cell 2000, 5: 695-705. 